\title{
PENCAPAIAN PERFORMA PADA KATUP VARIABEL TIMING FIXED TIMING UNTUK MESIN YANG OPTIMAL
}

\author{
KETUT ASTAWA \\ Jurusan Teknik Mesin, Universitas Udayana \\ E-mail: ketut.astawa@me.unud.ac.id
}

\begin{abstract}
ABSTRAK
Permasalahan yang didiskusikan pada penelitian ini adalah bagaimana perbedaan pembuangan emisi pada mesin dengan teknologi katup variable timing dan variable valve timing on a fixed volume pada mesin motor silinder 1300 cc. Katup variable timing adalah teknologi yang mengatur waktu membuka dan menutup katup masuk (intake valve) bahan bakar secara elektronik sesuai kondisi mesin. Hal ini akan membuat pencampuran udara dan bahan bakar yang masuk kedalam mesin menjadi efisien sehingga akan menghasilkan tenaga yang besar, hemat bahan bakar, dan emisi yang rendah. Penelitian emisi gas buang $\left(\mathrm{CO}, \mathrm{CO}_{2}, \mathrm{HC}, \mathrm{O}_{2}\right)$ ini dilakukan dengan pengujian dinamis, dimana kendaraan dalam keadaan terangkat dan diberi beban transmisi. Berbeda dengan pengujian pada umumnya yang dilakukan dengan pengujian statis, dimana kendaraan dalam keadaan diam dan tanpa beban. Pengujian ini dilakukan untuk mengetahui bagaimana kondisi emisi gas buang pada saat kendaraan dinamis (analogi untuk kendaraan berjalan). Secara umum, mesin dengan katup variable timing menghasilkan emisi yang lebih baik dibandingkan mesin dengan katup fixed timing. Semakin tinggi perputaran mesin dan beban kendaraan, maka sistem transmisi akan menghasilkan lebih sedikit CO dan $\mathrm{HC}$ serta semakin banyak $\mathrm{O}_{2}$ dan $\mathrm{CO}_{2}$.
\end{abstract}

Kata kunci: emisi gas buang, katup variabel timing, katup fixed timing

\begin{abstract}
Problems will be discussed in this research is how differences in exhaust emissions generated by engine with variable valve timing on a fixed volume of motor vehicle cylinder $1300 \mathrm{cc}$. Variable valve timing technology that is set when opening and closing the intake valve (intake valve) electronic fuel according to engine conditions. This will make mixing air and fuel that enters into an efficient machine that will produce great power, fuel economy and low emissions. Emissions research is done with dynamic testing, where the vehicle in a state of the load lifted and given transmission. Unlike the testing generally performed with static testing, where the vehicle is at rest and without a load. This test is performed to determine how the condition of exhaust gases when the vehicle dynamic (analogous to the vehicle running). In general, machines with variable valve timing to produce a better emissions than engines with fixed valve timing.
\end{abstract}

Keywords: exhaust gas, variable valve timing, valve timing fixed

\section{PENDAHULUAN}

Dengan berkembangnya zaman, teknologi dalam transportasi juga berkembang dengan pesat. Banyak teknologi yang dikembangkan dan telah diaplikasikan pada kendaraan yang diproduksi secara massal. Hal ini bertujuan untuk meningkatkan performa, keamanan dan kenyamanan kendaraan tersebut dalam menyikapi permintaan pasar (Borman dan Ragland, 1998).

Salah satu terobosan yang dikembangkan saat ini dalam dunia otomotif adalah penemuan teknologi pengaturan katup variable. Teknologi ini memberi pengaruh yang besar terhadap usaha meningkatkan tenaga, yang sebaliknya mampu menekan konsumsi bahan bakar serta emisi gas buang yang lebih baik. Katup variable timing adalah teknologi yang mengatur waktu membuka dan menutup katup masuk (intake valve) bahan bakar secara elektronik sesuai kondisi mesin. Hal ini akan membuat pencampuran udara dan bahan bakar yang masuk kedalam mesin menjadi efisien sehingga akan menghasilkan tenaga yang besar, hemat bahan bakar dan emisi yang rendah. Jumlah pencampuran udara dan bahan bakar yang lebih besar dan disesuaikan dengan pengaturan waktu membuka dan menutup katup masuk (intake valve) akan menghasilkan tenaga yang besar dan meningkatkan efisiensi mesin (Sucahyo dan Darmanto, 1997).

Teknologi katup variable timing memungkinkan mesin dapat menghisap pencampuran udara dan bahan bakar kedalam mesin lebih banyak dengan mengatur waktu buka-tutup katup masuk (intake 
valve) melalui komputer. Pengaturan waktu buka lebih lambat pada putaran mesin rendah dan lebih cepat pada putaran mesin tinggi akan membuat suplai pencampuran udara dan bahan bakar menjadi efisien, hasilnya performa mesin menjadi optimal untuk setiap kondisi kecepatan.

Saat putaran mesin tinggi aliran udara dan bahan bakar tidak dapat mengimbangi gerakan torak sehingga ada jeda aliran campuran udara dan bahan bakar saat katup hisap mulai dibuka (intake lag), untuk itu diperlukan memajukan waktu membukanya katup hisap bahkan sebelum piston mencapai titik mati atas. Sehingga katup over lapping menjadi besar yang berfungsi untuk meningkatkan sirkulasi gas buang dan memanaskan pencampuran udara dan bahan bakar, dengan pembakaran campuran udara dan bahan bakar yang murni dihasilkan output yang besar. Sedangkan pada putaran rendah kevakumaan di ruang bakar sangat tinggi dan mudah untuk mengalirkan bahan bakar ke ruang bakar, selain itu gerakan piston pun masih lambat sehingga tidak diperlukan katup over lapping. Hal ini mengakibatkan lebih sedikit campuran udara dan bahan bakar yang keluar bersama gas sisa pembakaran yang berarti hemat bahan bakar juga pembakaran yang sempurna akan dihasilkan output yang besar dan gas buang yang lebih baik.

\section{METODE}

Penelitian emisi gas buang ini dilakukan dengan pengujian dinamis, dimana kendaraan dalam keadaan terangkat dan diberi beban transmisi. Berbeda dengan pengujian pada umumnya yang dilakukan dengan pengujian statis, dimana kendaraan dalam keadaan diam dan tanpa beban. Pengujian ini dilakukan untuk mengetahui bagaimana kondisi emisi gas buang pada saat kendaraan dinamis (analogi untuk kendaraan berjalan).

Langkah-langkah pengujian yang dilakukan adalah pertama-tama, peralatan gas analyzer dipersiapkan, sebelum digunakan tunggu sampai proses kalibrasi selesai (automatic calibration). Kemudian, kuras bensin dalam tangki bensin dan masukan Pertamax ke dalam tangki. Lalu, hidupkan mesin kendaraan uji dengan katup fixed timing sampai mencapai temperatur kerja selama 10-15 menit. Setelah itu, angkat kendaraan dengan dongkrak dan pasang jack stand pada tempat yang telah ditentukan pada kendaraan. Lalu, tunggu beberapa menit, kemudian masukkan ujung probe gas analyzer ke ujung knalpot (muffler) minimal $20 \mathrm{~cm}$.

Atur putaran mesin pada posisi $1000 \mathrm{rpm}$, catat gas buang $\mathrm{CO}, \mathrm{CO}_{2}, \mathrm{HC}, \mathrm{O}_{2}$. pada tabel emisi yang telah disiapkan. Kemudian secara bertahap masukkan beban sistem dari kecepatan 1 hingga kecepatan 2 serta dicatat hasil emisi $\mathrm{CO}, \mathrm{CO}_{2}, \mathrm{HC}$, $\mathrm{O}_{2}$ untuk masing-masing kecepatan sistem transmisi. Pengambilan data diambil masing-masing tiga kali untuk setiap perubahan kecepatan sistem transmisi. Ulangi untuk pengujian emisi gas buang pada putaran $2000 \mathrm{rpm}, 3000 \mathrm{rpm}$, dan $4000 \mathrm{rpm}$ dengan diberi beban sistem transmisi kecepatan N, 1, 2 . Lakukan juga untuk mesin dengan katup variabel timing.

\section{HASIL DAN PEMBAHASAN}

Mekanisme katup membuka atau menutup intake valve dan exhaust valve pada waktu yang tepat untuk menarik percampuran udara-bahan bakar ke dalam cylinder dan membuang gas pembakaran ke luar. Rotasi pada crankshaft diteruskan ke camshaft melalui timing chain (timing belt), kemudian memutar cam. Jumlah teeth pada camshaft sprocket (pulley) dua kalinya crankshaft sehingga camshaft berotasi sekali atau setiap dua rotasi crankshaft. Bila camshaft berotasi, cam menekan valve untuk terbuka atau tertutup.

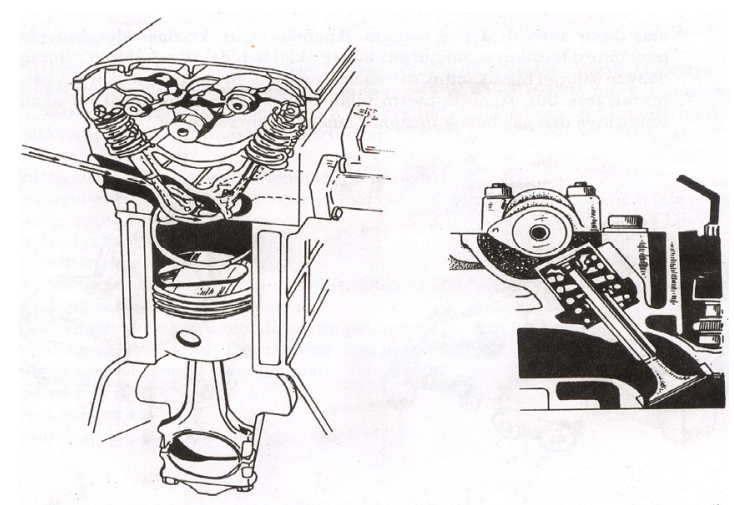

Gambar 1. Mekanisme Katup

Valve timing adalah waktu buka dan tutup intake valve dan exhaust valve yang dinyatakan dalam sudut crankshaft, dan disebut "diagram timing katup" ("valve timing diagram"). Setiap valve tidak terbuka dan tertutup bergantian pada TDC (Top Dead Center) dan BDC (Bottom Dead Center). Namun, intake valve terbuka sebelum TDC dan menutup setelah BDC dan exhaust valve terbuka sebelum BDC dan menutup setelah TDC. Adanya valve timing dimaksudkan untuk meningkatkan efisiensi pemasukan (intake) dan pembuangan (exhaust) dengan memanfaatkan momen enersia dengan cara mengatur timing-nya, membuka dan menutup valve lebih awal dan akhir sesuai dengan posisi piston. Dalam beberapa mesin, valve timing-nya dapat dirubah seperti pada VVT-i (Variable Valve Timing-intelligent). Pada sistem ini, yang dikontrol tidak hanya valve timing-nya saja, 
tapi juga jumlah angkatannya seperti pada VVTL-i (Variable Valve Timing and Lift-intelligent). Stabilitas saat idling, peningkatan output atau efisiensi EGR dari valve overlap dipergunakan secara efektif dengan membuat valve timing yang dapat dirubah.

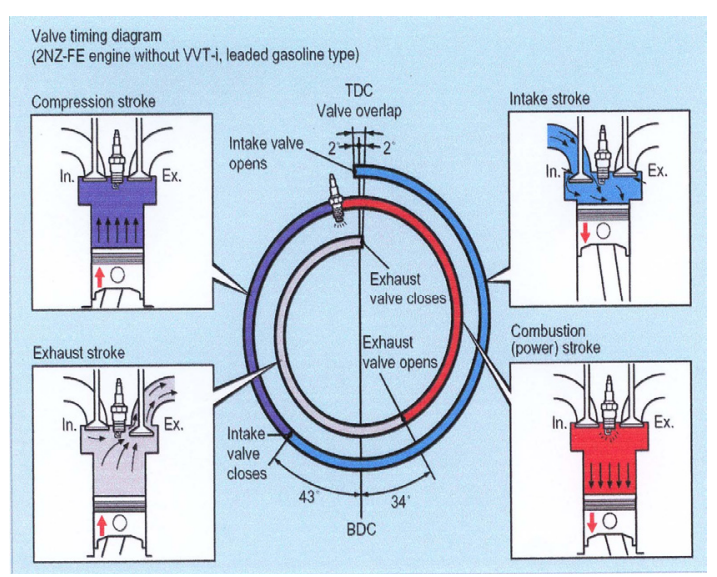

Gambar 2. Valve Timing

Umumnya, valve timing itu tetap (fixed), tetapi sistem VVT-i (Variable Valve Timing Intelligent) menggunakan tekanan hidraulik untuk menggeser rotasi intake camshaft dan mevariasikan valve timing. Cara ini memungkinkan untuk meningkatkan performance, meningkatkan efisiensi bahan bakar, dan menurunkan tingkat emisi. Jaring Loop yang digunakan dalam sistem VVT-i adalah sistem kontrol lup tertutup (close loop control), di mana sinyal keluarannya berpengaruh langsung pada aksi pengontrolan atau sistem kontrol berumpan balik. Sinyal kesalahan, yang merupakan selisih, antara sinyal masuk dan sinyal umpan balik diumpankan ke kontroler untuk memperkecil kesalahan dan membuat agar keluaran sistem mendekati harga yang diinginkan.dengan kata lain istilah lup tertutup berarti menggunakan aksi umpan balik untuk memperkecil kesalahan sistem.

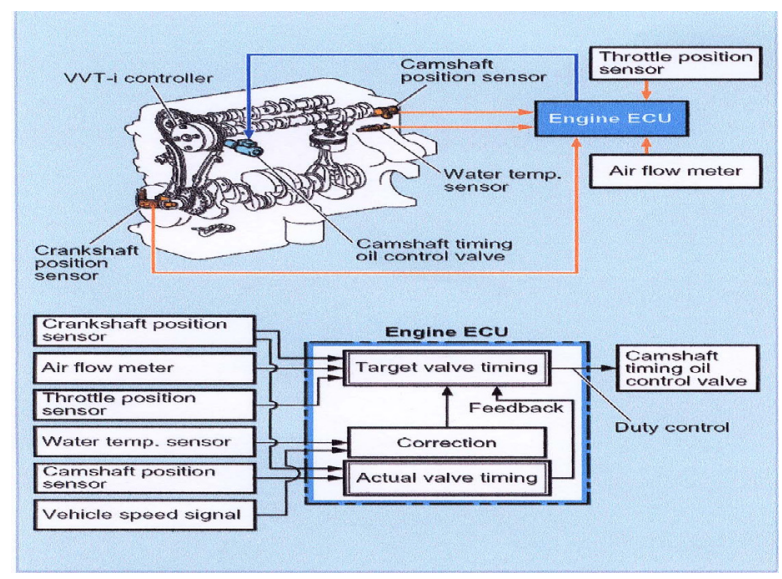

Gambar 3. Sistem VVT-i
Selama suhu rendah, selama kecepatan rendah dengan beban ringan, atau selama beban ringan, intake valve timing dimundurkan dan valve overlap dikurangi untuk menurunkan tertiupnya kembali gas buang ke sisi intake. Hal ini akan menstabilkan kondisi idling, meningkatkan efisiensi bahan bakar, dan starting yang mudah. Selama beban sedang, kecepatan rendah dan sedang dengan beban berat, intake valve timing dimajukan dan valve overlap ditambah untuk meningkatkan EGR internal dan mengurangi kerugian pemompaan (kompresi). Ini akan meningkatkan kontrol emisi dan efisiensi bahan bakar. Sebagai tambahan, pada saat yang sama waktu penutupan intake valve dimajukan untuk mengurangi pengisian balik pada sisi intake dan meningkatkan efisiensi volumetric.

Selama kecepatan tinggi dengan beban berat, intake valve timing dimajukan dan valve overlap ditambah untuk meningkatkan EGR internal dan mengurangi kerugian pemompaan (kompresi). Ini akan meningkatkan kontrol emisi dan efisiensi bahan bakar. Sebagai tambahan, pada saat yang sama waktu penutupan intake valve dimajukan untuk mengurangi pengisian balik pada sisi intake dan meningkatkan efisiensi volumetric. Intake valve timing dimundurkan dan valve overlap ditambah untuk meningkatkan EGR internal dan mengurangi kerugian pemompaan. Ini akan meningkatkan Kontrol emisi dan efisiensi bahan bakar. Sebagai tambahan, pada saat yang sama waktu penutupan intake valve dimajukan untuk mengurangi pengisian balik pada sisi intake dan meningkatkan efisiensi volumetric.

Aktuator sistem VVT-i terdiri dari VVT-i kontroller yang bertugas menggeser intake camshaft, tekanan oli yang merupakan gaya gerak VVT-i kontroller, dan camshaft timing oil kontrol valve untuk mengontrol saluran oli (Team Toyota, 2007a).

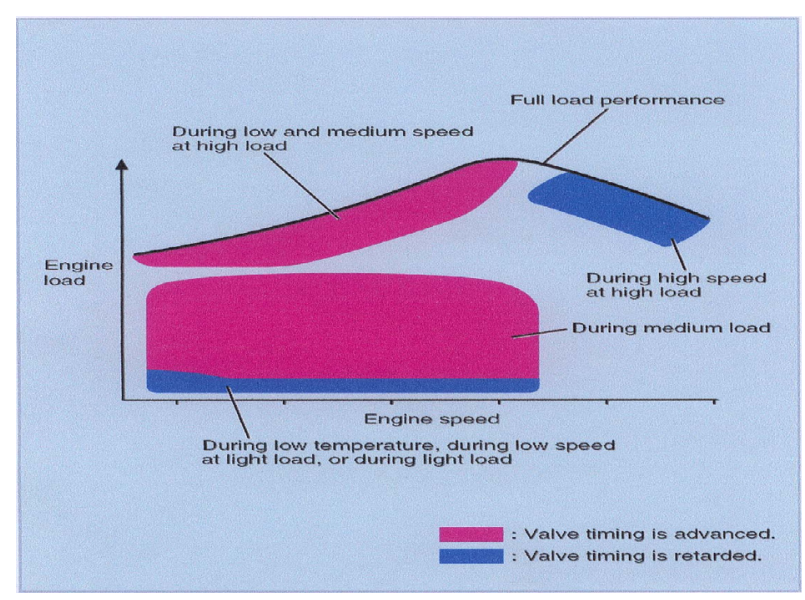

Gambar 4. Kurva VVT- i 


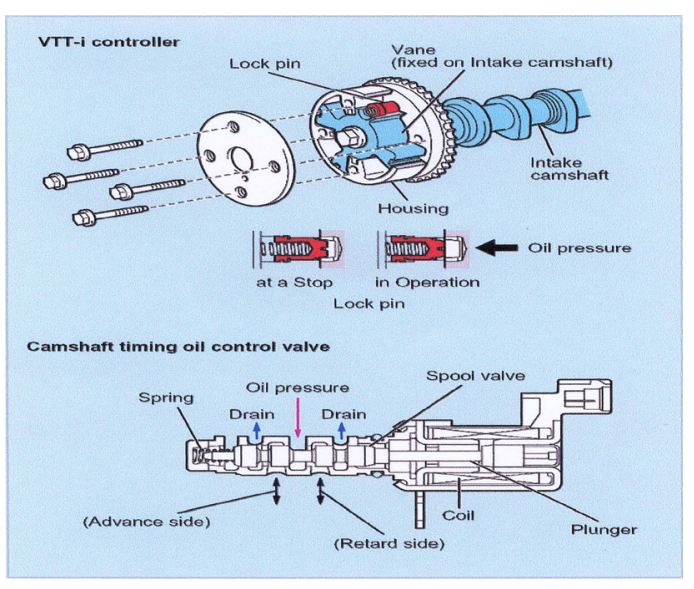

Gambar 5. Konstruksi VVT- i

Kontroler ini terdiri dari housing yang di gerakkan oleh timing chain dan vane yang dipasang secara tetap (fixed) pada intake camshaft. Tekanan oli yang dikirim dari sisi saluran pemaju atau pemundur intake camshaft memutar VVT-i kontroller vane pada arah melingkar untuk mengubah intake valve timing secara kontinyu. Saat mesin dimatikan, intake camshaft bergerak ke kondisi mundur maksimum untuk menjaga kemampuan starter. Ketika tekanan oli tidak mencapai VVT-i kontroller dengan segera setelah mesin di-start, lock pin mengunci mekanisme kerja VVT-i kontroller untuk start, lock pin menguci mekanisme kerja VVT-i kontroller untuk mencegah bunyi knocking (Team Toyota, 2007b).

Sebagai tambahan di atas, terdapat tipe dimana piston bergerak dalam arah axial diantara alur spiral (helical) dari roda gigi luar (berhubungan ke housing) dan roda gigi dalam (langsung menempel ke camshaft) untuk menggeser fase camshaft. Camshaft timing oil valve ini merupakan kontrol beban dari ECU mesin untuk mengontrol posisi spool valve dan mendistribusikan tekanan oli yang digunakan ke VVT-i kontroller ke sisi maju atau mundur. Saat mesin dimatikan, intake valve timing berada pada sudut mundur maksimum.

Camshaft timing oil kontrol valve memilih saluran ke VVT-i controller sesuai dengan jumlah arus dari ECU mesin. VVT-i controller merotasikan intake camshaft untuk menyesuaikan dengan posisi tekanan oli yang diberikan, untuk memajukan, memundurkan atau mempertahankan valve timing. ECU mesin mengkalkulasi valve timing optimal di bawah beragam kondisi pengoperasian sesuai dengan putaran mesin, volume udara intake, posisi throttle, dan temperatur cairan pendingin untuk mengontrol camshaft timing oil kontrol valve. Sebagai tambahan, ECU mesin menggunakan sinyal dari camshaft position sensor dan crankshaft position sensor untuk mengkalkulasikan valve timing actual, dan mengeksekusi ke arah feedback untuk mendapatkan valve timing sesuai target.

Pada saat camshaft timing oil kontrol valve berada pada keadaan sebagaimana tampak pada gambar oleh ECU mesin, tekanan oli beraksi pada timing advance side vane chamber untuk memutar intake chamshaft ke arah pengajuan valve timing.

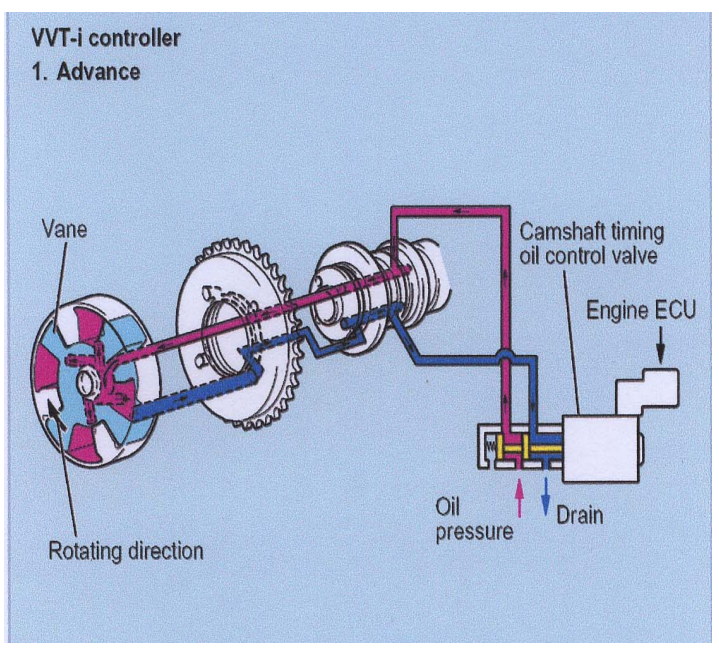

Gambar 6. VVT-i Saat Maju (advance)

Saat camshaft timing oil kontrol valve berada pada kondisi sebagaimana tampak pada gambar oleh ECU mesin, tekanan oli beraksi pada timing retard side vane chamber untuk memutar intake camshaft ke arah pengunduran valve timing.

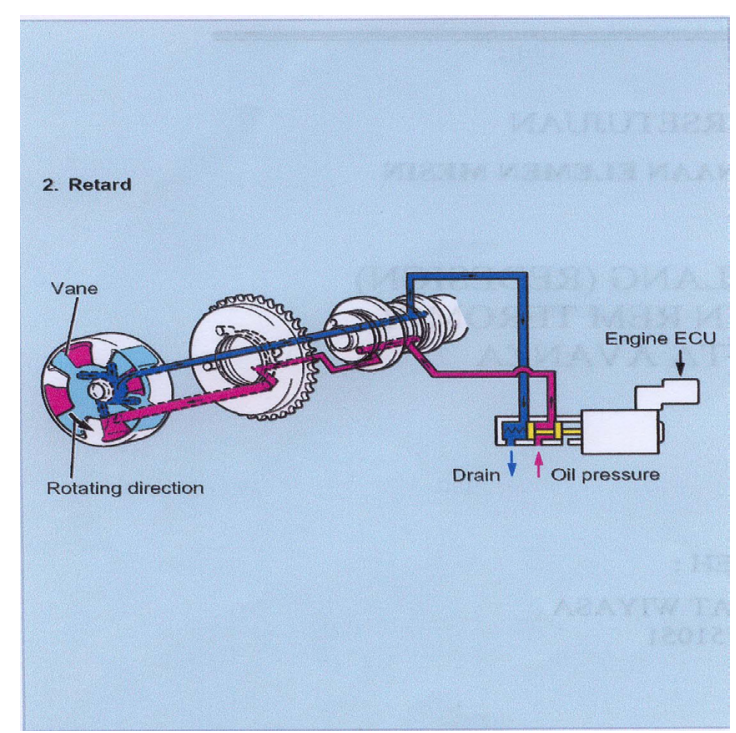

Gambar 7. VVT-i Saat Mundur (Retard)

ECU mesin mengkalkulasikan sudut target valve timing sesuai dengan kondisi operasi. Setelah mengeset ke target valve timing, camshaft timing oil kontrol valve menjaga saluran oli tertutup seperti 
tampak pada gambar, untuk mempertahankan arus valve timing (Jenbacher, 1997).

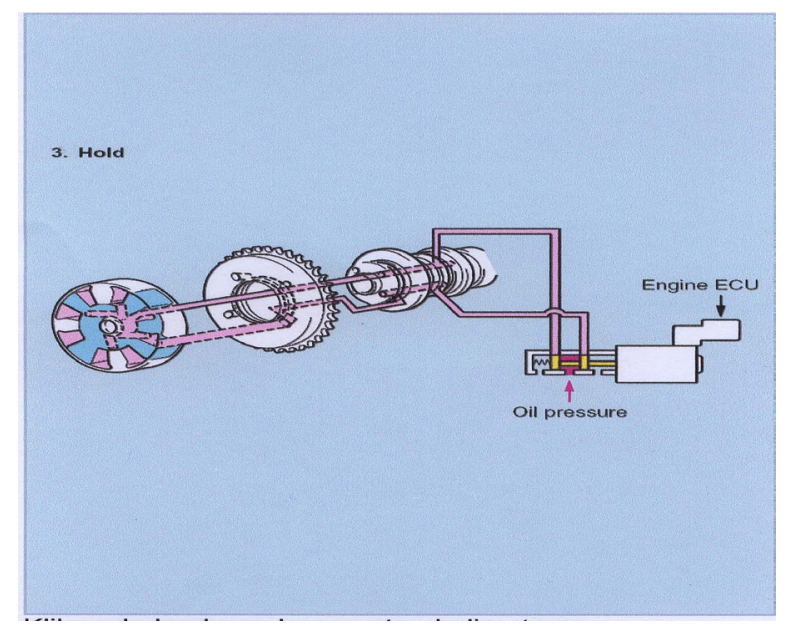

Gambar 8. VVT-i Saat Tahan (hold)

Besarnya nilai gas buang standar pada kendaraan sesuai dengan keputusan Menteri Negara Lingkungan Hidup tahun 1993 adalah sebagai berikut.

Tabel 1. Standar Emisi Gas Buang Keputusan Menteri Negara Lingkungan Hidup No. KEP.35/ MENLH/10/93

\begin{tabular}{ccl}
\hline No. & Gas Buang & Besar Nilai \\
\hline 1 & $\mathrm{CO}$ & Max $3 \%$ vol \\
2 & $\mathrm{HC}$ & Max $400 \mathrm{ppm}$ \\
3 & $\mathrm{CO}_{2}$ & Max $12 \%$ vol \\
4 & $\mathrm{O}_{2}$ & Max $2 \%$ vol \\
\hline
\end{tabular}

Dari hasil pengujian yang dilakukan pada variasi putaran mesin yang telah ditentukan, diperoleh emisi gas buang terhadap masing-masing putaran mesin seperti yang ditampilkan pada Gambar 9 di bawah ini.

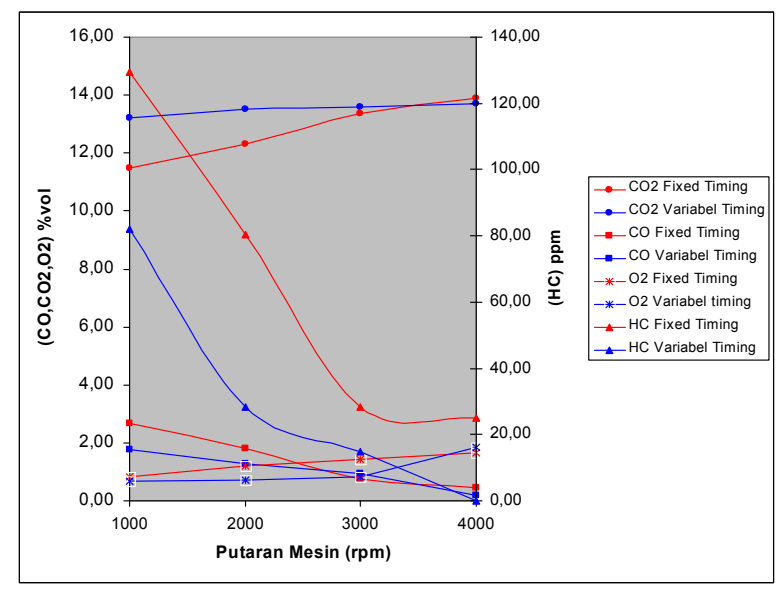

Gambar 9. Grafik Emisi yang Dihasilkan pada Posisi Transmisi Netral
Seperti yang terlihat pada grafik, untuk mesin dengan fixed timing pada putaran mesin $1000 \mathrm{rpm}$ sampai putaran mesin $4000 \mathrm{rpm}$ terjadi penurunan gas CO yaitu dari $2,69 \%$ volume menjadi $0,46 \%$ volume. Untuk mesin dengan variabel timing pada putaran mesin $1000 \mathrm{rpm}$ sampai dengan $4000 \mathrm{rpm}$ terjadi penurunan persentase gas $\mathrm{CO}$ yaitu dari $1,76 \%$ vol sampai $0,20 \%$ volume.

Semakin tinggi putaran mesin akan menghasilkan $\mathrm{CO}_{2}$ yang semakin besar pada gas buang. Ini berarti pembakaran yang terjadi di dalam ruang bakar semakin baik, untuk mesin dengan katup fixed timing pada putaran mesin $1000 \mathrm{rpm}$ sampai $4000 \mathrm{rpm}$ terjadi peningkatan persentase gas $\mathrm{CO}_{2}$ yaitu dari $11,50 \%$ volume sampai $13,90 \%$ volume. Untuk mesin dengan katup variable timing terlihat pada grafik yaitu pada putaran mesin $1000 \mathrm{rpm}$ sampai $4000 \mathrm{rpm}$ terjadi peningkatan persentase gas $\mathrm{CO}_{2}$ yaitu dari 13,20\% volume sampai dengan $13,70 \%$ volume.

Pada grafik terlihat pada putaran mesin $1000 \mathrm{rpm}$ sampai 4000 rpm untuk mesin dengan katup fixed timing terjadi penurunan gas $\mathrm{HC}$ yaitu dari $129,33 \mathrm{ppm}$ sampai 25,00 ppm. Untuk mesin dengan katup variabel timing pada putaran mesin $1000 \mathrm{rpm}$ sampai 4000 rpm terjadi penurunan gas HC yaitu dari 82,00 ppm sampai 0 ppm.

Untuk mesin dengan fixed timing dapat dilihat pada grafik, dimana pada putaran mesin $1000 \mathrm{rpm}$ sampai $4000 \mathrm{rpm}$ terjadi peningkatan persentase gas $\mathrm{O}_{2}$ yaitu dari $0,82 \%$ volume sampai $1,67 \%$ volume. Untuk mesin dengan variabel timing, dimana pada putaran mesin $1000 \mathrm{rpm}$ sampai $4000 \mathrm{rpm}$ terjadi peningkatan persentase gas $\mathrm{O}_{2}$ yaitu dari $0,69 \%$ volume sampai $1,83 \%$ volume.

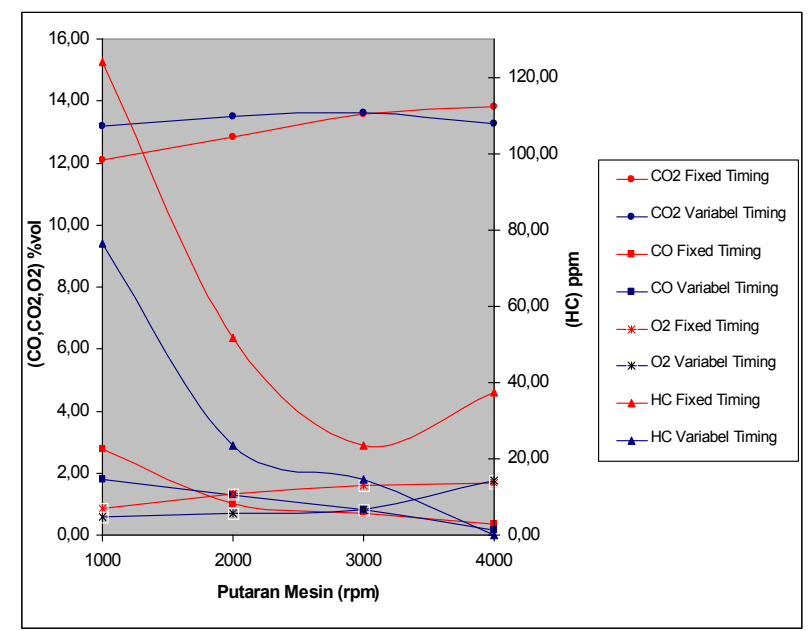

Gambar 10. Grafik Emisi yang Dihasilkan pada Posisi Transmisi 1 
Untuk mesin dengan katup fixed timing pada putaran mesin $1000 \mathrm{rpm}$ sampai putaran mesin 4000 rpm terjadi penurunan gas $\mathrm{CO}$ yaitu dari $2,76 \%$ volume menjadi $0,36 \%$ volume. Untuk mesin dengan katup variabel timing pada putaran mesin 1000 rpm sampai dengan $4000 \mathrm{rpm}$ terjadi penurunan persentase gas CO yaitu dari $1,79 \%$ vol sampai $0,16 \%$ volume.

Semakin tinggi putaran mesin akan menghasilkan $\mathrm{CO}_{2}$ yang semakin besar pada gas buang. Ini berarti pembakaran yang terjadi di dalam ruang bakar semakin baik, untuk mesin dengan katup fixed timing pada putaran mesin $1000 \mathrm{rpm}$ sampai $4000 \mathrm{rpm}$ terjadi peningkatan persentase gas $\mathrm{CO}_{2}$ yaitu dari $12,10 \%$ volume sampai $13,80 \%$ volume. Untuk mesin dengan katup variabel timing terlihat pada grafik yaitu pada putaran mesin $1000 \mathrm{rpm}$ sampai $3000 \mathrm{rpm}$ terjadi peningkatan persentase gas $\mathrm{CO}_{2}$ yaitu dari $13,20 \%$ volume sampai dengan $13,63 \%$ volume sedangkan pada putaran $4000 \mathrm{rpm}$ terjadi penurunan persentase volume gas $\mathrm{CO}_{2}$ menjadi $13,27 \%$ volume.

Pada gambar 10 terlihat pada putaran mesin $1000 \mathrm{rpm}$ sampai $4000 \mathrm{rpm}$ untuk mesin dengan katup fixed timing terjadi penurunan gas $\mathrm{HC}$ yaitu dari 124,00 ppm sampai 37,33 ppm. Untuk mesin dengan katup variabel timing pada putaran mesin $1000 \mathrm{rpm}$ sampai $4000 \mathrm{rpm}$ terjadi penurunan gas HC yaitu dari 76,33 ppm sampai 0 ppm.

Untuk mesin dengan fixed timing dapat dilihat pada grafik, dimana pada putaran mesin $1000 \mathrm{rpm}$ sampai $4000 \mathrm{rpm}$ terjadi peningkatan persentase gas $\mathrm{O}_{2}$ yaitu dari $0.87 \%$ volume sampai $1,66 \%$ volume. Untuk mesin dengan variabel timing, dimana pada putaran mesin $1000 \mathrm{rpm}$ sampai $4000 \mathrm{rpm}$ terjadi peningkatan persentase gas $\mathrm{O}_{2}$ yaitu dari $0,59 \%$ volume sampai $1,74 \%$ volume.

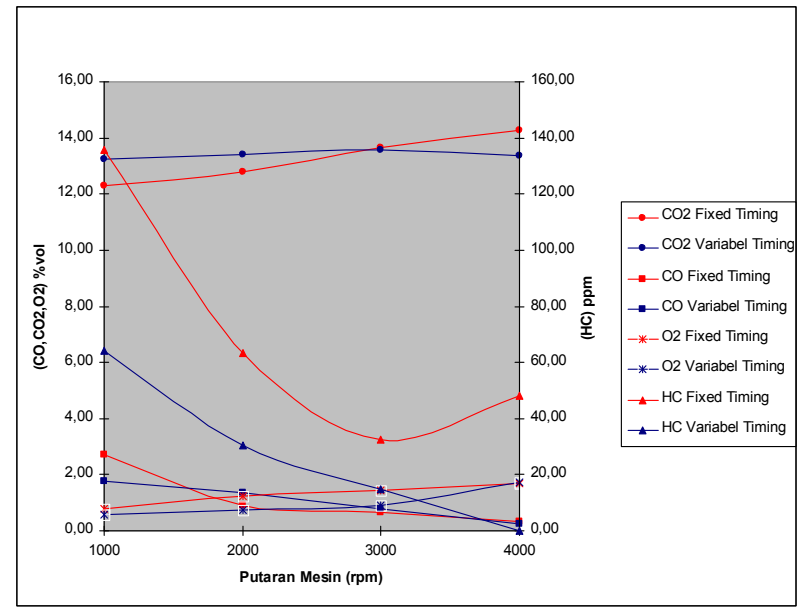

Gambar 11. Grafik Emisi yang dihasilkan pada Posisi Transmisi 2
Untuk mesin dengan katup fixed timing pada putaran mesin $1000 \mathrm{rpm}$ sampai putaran mesin $4000 \mathrm{rpm}$ terjadi penurunan gas CO yaitu dari $2,70 \%$ volume menjadi $0,33 \%$ volume. Untuk mesin dengan katup variabel timing pada putaran mesin 1000 rpm sampai dengan $4000 \mathrm{rpm}$ terjadi penurunan persentase gas CO yaitu dari 1,76\% vol sampai $0,25 \%$ volume.

Semakin tinggi putaran mesin akan menghasilkan $\mathrm{CO}_{2}$ yang semakin besar pada gas buang. Ini berarti pembakaran yang terjadi di dalam ruang bakar semakin baik, untuk mesin dengan katup fixed timing pada putaran mesin $1000 \mathrm{rpm}$ sampai $4000 \mathrm{rpm}$ terjadi peningkatan persentase gas $\mathrm{CO}_{2}$ yaitu dari $12,30 \%$ volume sampai $14,27 \%$ volume. Untuk mesin dengan katup variabel timing terlihat pada grafik yaitu pada putaran mesin $1000 \mathrm{rpm}$ sampai $3000 \mathrm{rpm}$ terjadi peningkatan persentase gas $\mathrm{CO}_{2}$ yaitu dari $13,23 \%$ volume sampai dengan $13,57 \%$ volume sedangkan pada putaran $4000 \mathrm{rpm}$ terjadi penurunan persentase volume gas $\mathrm{CO}_{2}$ menjadi $13,37 \%$ volume.

Pada gambar 11 terlihat pada putaran mesin $1000 \mathrm{rpm}$ sampai $4000 \mathrm{rpm}$ untuk mesin dengan katup fixed timing terjadi penurunan gas $\mathrm{HC}$ yaitu dari 135,67 ppm sampai 48,00 ppm. Untuk mesin dengan katup variabel timing pada putaran mesin $1000 \mathrm{rpm}$ sampai $4000 \mathrm{rpm}$ terjadi penurunan gas HC yaitu dari 64,33 ppm sampai 0 ppm. Untuk mesin dengan fixed timing dapat dilihat pada grafik, dimana pada putaran mesin $1000 \mathrm{rpm}$ sampai 4000 rpm terjadi peningkatan persentase gas $\mathrm{O}_{2}$ yaitu dari $0,77 \%$ volume sampai $1,68 \%$ volume.Untuk mesin dengan variabel timing, dimana pada putaran mesin $1000 \mathrm{rpm}$ sampai $4000 \mathrm{rpm}$ terjadi peningkatan persentase gas $\mathrm{O}_{2}$ yaitu dari $0,57 \%$ volume sampai $1,73 \%$ volume.

\section{SIMPULAN}

Dari analisis hasil pengujian dapat disimpulkan bahwa secara umum mesin dengan katup variable timing menghasilkan emisi yang lebih baik dibandingkan mesin dengan katup fixed timing. Semakin tinggi putaran mesin dan beban sistem transmisi akan menghasilkan emisi CO dan HC yang semakin menurun dan $\mathrm{CO}_{2}$ dan $\mathrm{O}_{2}$ yang semakin meningkat. Mesin dengan katup variabel timing mengkontrol waktu pembukaan katup hisap untuk mencapai performa mesin yang optimal pada berbagai kondisi pengendaraan. Dan mengatur output yang dikeluarkan mesin sesuai dengan kebutuhan. 


\section{DAFTAR PUSTAKA}

Borman, G.L. and Ragland, K.W., 1998. Combustion Engineering, International Edition, McGraw-Hill, Singapura

Jenbacher, 1997. Manual Book of Gas Engine, McGrawHill.
Sucahyo, B. and Darmanto, S., 1997. Otomotif Mesin Tenaga, Tiga Serangkai, Solo

Team Toyota, 2007a. New Car Features Vios, PT Toyota Astra Motor, Jakarta.

Team Toyota, 2007b. Diagnosis Technician Engine, PT Toyota Astra Motor, Jakarta. 